\title{
Comments
}

\section{UNUSUAL STATUTORY REMEDIES FOR THE DEADLOCKED CORPORATION IN CALIFORNIA: VOLUNTARY DISSO- LUTION AND THE PROVISIONAL DIRECTOR}

The deadlocked corporation, unable either to act upon or react against its environment, is an organism with an essentially economic purpose that has ceased to function economically. Because of the frustration of purpose which a deadlock invariably causes, lawyers in planning and drafting corporate documents, judges in deciding disputes between the contending factions within a corporation, and legislators in providing statutory remedies, have all been concerned with finding ways to avoid this problem. ${ }^{1}$ In addition to usual methods of preventing and breaking deadlocks, ${ }^{2}$ California law provides two rather unusual statutory remedies. Section 4600 of the Corporations Code enables either faction in an evenly divided corporation to voluntarily dissolve without a majority vote, and section 819 of the Code provides for the appointment of a provisional director in certain situations where deadlock exists. This Comment will analyze the two statutes and the cases interpreting and applying them with a view toward providing the lawyer with an understanding of how and when resort to these remedies will be helpful in meeting the problems of a paralyzed close corporation.

\section{THE VOLUNTARY DISSOLUTION RIGHT IN CALIFORNIA AS A REMEDY} POR THE DEADLOCKED CORPORATION

Statutes in most States require at least a majority vote by the shareholders for voluntary dissolution of a corporation. ${ }^{3}$ In California, on the other hand, section 4600 of the Corporations Code provides that any corporation may be voluntarily dissolved by the vote or written consent of an even 50 percent of the shareholders. Thus, the holders of 50 percent of the voting shares in a close corporation may

1 Problems of deadlock and proposals for avoiding them bave been the subject of extensive discussion in legal literature. See generally 2 O'NeAL, Close Corporations ch. IX (I958); Barkin, Deadlock and Dissolution in Florida Closed Corporations: Litigating and Planning, 13 U. MtaMar L. REv. 395 (1959); Symposium-The Close Corporation, 52 Nw. U.L. REv. 345 (1957) ; Israels, The Sacred Cow of Corporate Existence: Problems of Deadlock and Dissolution, 19 U. Cer. L. Rev. 778 (1952).

2 For a discussion focused primarily upon the mvoluntary dissolution right in California, see Comment, 43 CaIrf. L. Rev. 514 (1955).

3 Des. Code ANn. tit. 8, \$275 (1953) (two-thirds); Irc. ANs. Stat. ch. 32, \$8 157.75-.76 (Smith-Hurd 1954) (unanimous, or two-thirds at meeting pursuant to directors' recommendation); IOWA CoDE $\$ 491.23$ (1958) (unanimous, or per articles); MASs. LAwS ANN. ch. 155, \& 50 (1959) (majority or per articles); N.Y. Gen. Corp. LAw $\$ 102$ (majority); PA. Stat. ANN. tit. 15, $\$ 2852-1102$ (1958) (unanimous, or majority at meeting pursuant to directors' recommendation).

\& CAL. CORP. CODE \& 4600: "Any corporation may elect to wind up its affairs and voluntarily dissolve by the vote or written consent of sharebolders or members representing 50 percent or more of the voting power." 
resort to voluntary dissolution as a statutory remedy for any deadlock. However, since dissolution "falls with such finality" upon the interests of all the shareholders, section 4600 as a cure for corporate paralysis will often be worse than the disease.

On its face section 4600 imposes no restriction upon the right to dissolve once 50 percent of the voting power consents. However, it has been held in In re Security Fin. $\mathrm{Co}^{5}$ that the right granted by the statute was subject to equitable limitations -specifically, good faith. But the dissolving shareholder's desire to protect his investment was said to be a proper motive for consenting to dissolution in spite of the fact that the corporation was making record profits at the time. Moreover, injury to the corporation was not a factor to be considered, and prior conduct by the dissolving shareholder in contravention of an agreement to notify other shareholders of his business dealings was not sufficient to establish bad faith as to a later dissolution. ${ }^{8}$ Therefore, it would seem that the duty of good faith required of a dissolving shareholder is of a limited and selfish sort. It is not the same standard of good faith used to test the actions of directors and controlling shareholders in the general conduct of corporate affairs. Where no advantage over other shareholders is gained, no prejudice to third parties results, and no other way out is available, the good faith requirement will be satisfied by any conduct short of fraud.

This inconsistency between judicially engrafting a good faith limitation upon a shareholder's statutory right to dissolve and yet permitting any conduct short of fraud to come within the limitation is unfortunately in line with the weight of authority. ${ }^{7}$ It is submitted that the crucial factor should be not the good faith of the dissolving shareholder, but rather the effect dissolution will have on the inter-ests of other shareholders. A rational approach to the problem would be to subject actions of a controlling shareholder in dissolving, and his actions with reference to the general conduct of corporate affairs, to the same objective test-fairness to

649 Cal.2d 370, 317 P.2d 1 (1957); De Capriles, Business Organizations, 34 N.Y.U.L. REv. 337, 363 (1959).

${ }^{6}$ In the instant case a partnership engaged in the business of making personal loans and buying conditional sale contracts decided to incorporate. $A$ was issued one-half the voting shares and became the general manager. $B$ and $C$ were issued one-quarter each and agreed to procure bank loans and lend their credit standings to the corporation. The articles and by-laws required unanimity for all acts of the board of directors and for the exercise of powers vested in the voting shareholders. Transfers of shares were restricted to transferees who either agreed to disenfranchisement of the transferred shares, or else consented to the unanimity provisions of the articles and by-laws. Dissension centered around the refusal of $B$ and $C$ to permit either a salary increase for $A$ or a dividend declaration by the corporation, although the business was prosperous and constantly expanding. Finally, $B$ and $C$ refused to buy $A$ 's shares when they were offered, or sell theirs to him at the offered price. In such a situation dissolution was the only way out for $A$. The structure of the corporation and its subsequent voluntary dissolution at a time of record profits demonstrates the proposition that in a close corporation the tighter the restrictions the sooner trouble will start unless compatability and community of purpose between the shareholder-managers are present.

7 "The general rule is that where a statute confers power on a majority, or a certain per cent, of the stockholders to dissolve, the right is absolute, so far as the motives of the majority are concerned, in the absence of actual fraud, and not subject to judicial review on behalf of minority stockholders. . . But even where the dissolving stockholders act in accordance with the letter of the statute, they must do so in good faith." 16 Fietcres, Cyciopedia of CorPORATIONS $\$ 8022$ (1942). It is interesting to note that the vacated opinion of the district court of appeal in In re Sectrity Fin. Co. relied exclusively upon the "general rule" as quoted. In re Security Fin. Co., 308 P.2d 531, 534 (Cal. App. 1957) (vacated). On the other hand, the supreme court, in affirming, announced the good faith qualification, but in so doing stressed the fact that the other shareholders would suffer no disadvantage. 49 Cal. $2 \mathrm{~d}$ at $378,317 \mathrm{P} .2 \mathrm{~d}$ at 6 . 
the other parties concerned-thus obviating the necessity of paying lip service to "good faith" without investigating "motive" in either case.

The principal unanswered question regarding voluntary dissolution in California is whether section 4600 creates a right that is mandatory or merely permissive. ${ }^{8}$ If the statute is interpreted as conferring a mandatory right upon 50 percent of the shareholders, any alteration or abridgement of that right in the articles or by-laws will be ineffective, and likewise a shareholders' agreement should fare no better. ${ }^{9}$ On the other hand, if section 4600 is interpreted as permissive and essentially remedial, it may be altered or waived by the shareholders. Because the effect of any special procedures for the internal resolution of deadlocks will largely depend upon the nature of the voluntary dissolution right, and since the question whether section 4600 should be construed as mandatory or permissive is as yet undecided, the problem deserves extended discussion.

Arguments in behalf of a mandatory construction for the voluntary dissolution right are particularly strong in California. The proposition that the "dissolution of corporations is a peculiar function which resides in the legislature and is conferred upon courts only by explicit legislative authority" has been given court approval. ${ }^{10}$ From this it may be reasoned that since the legislature has provided an unusually detailed statutory scheme governing both voluntary and involuntary dissolution it must have intended that these statutes be mandatory and exclusive. Intermediate appellate courts in two cases decided prior to In re Security Fin. Co. have favored this view in dicta.

In Stubbs v. Jones ${ }^{11}$ it was held that the trustee of an express trust who is the legal owner of all the shares of a corporation can effectively consent to dissolution under section 4600 even though such a consent might constitute a breach of fiduciary duty to the beneficiaries of the trust. The theory used to justify the result

8 In In re Security Fin. Co. the question was not presented because a shareholders' agreement specifically provided that, notwithstanding any provisions of that agreement or the articles or by-laws of the corporation, any shareholder could dissolve pursuant to California law. 49 Cal. $2 \mathrm{~d}$ at $379-80,317$ P.2d at 7.

9 The relation between articles, by-laws, and shareholders' agreements is outside the general scope of this Comment. For a view that there is no logical basis for a distinction between the enforceability of articles or by-laws and shareholders' agreements that deviate from the statutory norm, although such a distinction has been made in a few cases, see Comment, 43 Car.rF. L. REV. 514, 521 (1955). The secretary of state makes no distinction in this regard. See text of Letter quoted in note 17 infra. For the practical differences which may result from the placement of provisions with particular reference to Cahfornia problems, see: CaL. Contununnc Educ. of the Bar, Advisinc CaItfornta Business Enterprises 410-11 (1958).

In the context of the widely held corporation, agreements between various groups of shareholders should have a legal significance different and apart froun corporate articles and by-laws. Several of many shareholders should be able to agree to govern themselves as a group in a manner in which the corporation as an entity could not do, without being beld to violate a statute. But in the context of the close corporation where all the shareholders are parties to an agreement, the corporation inust necessarily be governed by its terms. In fact, in a close corporation where the shareholders are also directors and managers a unanimous shareholders' agreement, hecause of its lack of amendability, may more effectively circumscribe corporate action than either articles or by-laws. For this reason there should be no distinction between the enforceability of articles, by-laws and shareholders' agreements when all the shareholders in a close corporation are in agreement. See further, text accoinpanying note $39 \mathrm{infra}$.

1016 Fietcher, CyCLOPEDIA OF Corporations $\$ 8097$ (1942), quoted in Stubbs v. Jones, 121 Cal. App. 2d 218, 222, 263 P.2d 100, 102 (1953).

11121 Cal. App. 2d 218, 263 P.2d 100 (1953). 
was that the statute lays down "no conditions for the dissolution of corporations other than that the specific statutory requirements be met...."12

In In re Mayellen Apartments, Inc. ${ }^{13}$ it was held that voluntary dissolution was not precluded by an article which prohibited the "sale or other disposition" of corporate property without unanimous shareholder approval. It was contended that unanimous consent for a sale was lacking since only 12 out of 16 shareholders had voted for dissolution, a procedure necessarily involving a sale of assets. Dissolution, it was asserted, constituted a breach of contract between the corporation and its shareholders. ${ }^{14}$ In deciding the case, the court based its holding upon the undoubted reserved power in the legislature to provide voluntary dissolution rights for the shareholders of any corporation, notwithstanding contrary articles and by-laws. The contract between the corporation and its shareholders was held to be defined by the applicable statutes, articles, and by-laws, with the statutes controlling. ${ }^{15}$ No one may quarrel with this reasoning so far as it goes. But the court stopped there, and thus disposed of the case without directly considering the nature of section 4600 itself. No reference was made to the issue that should have been dispositive of the merits, i.e., whether the legislature had actually provided in section 4600 a mandatory or a permissive right. ${ }^{16}$

A final argument favoring a mandatory construction for section 4600 , of more practical than legal significance for the lawyer, is that the secretary of state will not file articles or by-laws that alter in any manner the voluntary dissolution right provided by statute. ${ }^{17}$ This nieans that whatever may be the proper construction

12 Id. at 223,263 P.2d at 103 . The instant case was an action by the trustee against the beneficiaries to have it declared that trustee was authorized to sell and convey land that comprised the total assets of a corporation which trustee as sole shareholder had previously dissolved. The issues in such a case are different from a case where another shareholder contests dissolution. Shareholders have a direct interest in the corporation whose shares they hold, while beneficiaries have only an indirect interest in a corporation whose shares are part of the trust corpus.

13134 Cal. App. 2d 298, 285 P.2d 943 (1955).

14 Id. at 302,285 P.2d at 946 . The corporation involved in the instant case was organized for the purpose of owning and operating a cooperative apartment building, and each share in the corporation carried with it the exclusive right to occupy a specified apartment. The grounds for dissolution asserted by the majority were that dissension between the majority and minority had so disrupted normal living conditions that individual shareholders who desired to sell out had been unable to secure buyers because of the undesirability of living where a spirit of bickering prevailed. Therefore, in this case, as in In re Security Fin. Co., apart from dissolution, no other way out was available.

15 Id. at 304, 285 P.2d at 947.

${ }^{16}$ By expressly delimiting the contractual rights of shareholders by the articles, by-laws and applicable statutes the case leaves open the possibility of a distinction between these rights and those created by a seperate shareholders' agreement. For the reasons stated in note 9 supra, this distinction should not be adopted for a close corporation where all the shareholders are parties to the agreement. However, should it be concluded that $\$ 4600$ does confer a mandatory right upon the shareholders, the instant case would be good authority for the proposition that such a right is granted to the shareholders only vis-à-vis the corporation, and has nothimg to do with shareholders' rights created by agreement among themselves.

17 In a letter to this writer dated Novemher 17, 1959, the secretary of state stated his views as follows: "It is still the position of this office that neither articles of incorporation nor by-laws may authorize the voluntary dissolution of a corporation by the vote or written consent of less than fifty per cent of the voting power, nor may the articles or by-laws require greater than the fifty per cent approval of shareholders required by statute. We thimk there can be no question but that where such a right is conferred upon a given percentage of shareholders by statute, that right cannot be altered or enlarged by the articles or by-laws nor waived by agreement of shareholders. We are aware of no case law on the specific subject in the State of Califoruia but the case of Gaskill v. Gladys Belle Oil Co., 16 Del. Ch. 289, 146 Atl. 337 [1929] 
of section 4600 , attempted deviations from the terms of the statute should be embodied in a shareholders' agreement.

Turning now to arguments in behalf of a permissive construction of section 4600 , the most obvious and direct is that the statute itself is cast in permissive language- "Any corporation may elect to ... voluntarily dissolve ...." (Emphasis added.) The purpose of dissolution statutes is to protect shareholders and not the public generally. Therefore, absent mandatory language in the statute, it may be fairly argued that shareholders should be permitted to limit their statutory rights in this regard. ${ }^{18}$

The general rule is that one may waive the benefits of a statutory remedy provided he does not thereby contravene public policy. In a number of decisions in other States this proposition has been used to support a conclusion that statutes conferring voluntary dissolution rights upon shareholders are permissive. ${ }^{10}$ The theory of these cases is that there is no public policy against permitting shareholders inter sese to establish dissolution riglts and procedures that are at variance with the statutory norm, provided the variations are for a reasonable purpose and are fair to those concerned.

There is some indication that the California Supreme Court will not follow the

dealing with corporation laws which for all practical purposes were identical with the existing law of California establishes that such statutory rights may not be waived or altered by the shareholders."

Gaskill v. Gladys Belle Oil Co., 16 Del. Ch. 289, 146 Atl. 337 (1929), cited in the secretary's letter, suspra, involved the question whether a by-law which increased the rights of preferred sliares was valid in view of a Delaware statute which provided that "every corporation shall have power to create two or more classes of stock, with such ... preferences ... as shall be stated ... . in the Certificate of Incorporation. . . . Unless its original or amended charter ... sliall so provide, no corporation shall create preferred stock." Quoted id. at 293, 146 Atl. at 339. It was held in Gaskill that a by-law which attempted to provide what the statute required to be stated in the articles was invalid. This case, which gives mandatory effect to a statute requiring designation of stock preferences in the articles, is not applicable to 84600 , even by analogy. The wording of the Delaware statute is clearly mandatory, while that of $\$ 4600$ is permissive. The purpose of the requirement that preferences be stated in the articles is so that "those who contemplate the acquisition of stock in Delaware corporations may have a sure and certain place to which they may resort for authoritative information touching the capital structure of the concern into which they contemplate buying." Gaskill v. Gladys Belle Oil Co., suppra at 294, 146 Atl. at 339. Thus, the purpose of the Delaware statute is to protect the investing public, while the purpose of dissolution statutes is to protect the sharcholders. It is submitted that the California Secretary of State is relying upon scant authority for his position that $\$ 4600$ creates a mandatory right. For a further discussion of the position of the secretary of state in this matter, see Comment, 43 Carm. L. REv. 514, 518 n.19 (1955).

18 See 2 O'NeAL, CLOSE CORPoRATIONS $\$ 9.06$ (1958).

19 In Leventbal v. Atlantic Fin. Corp., 316 Mass. 194, 55 N.E.2d 20 (1944), the court gave effect to an agreement between two shareholders prohibiting either from dissolving a corporation except in ways specified in the agreement, even though a statute specified other grounds for dissolution. However, the dissolution statute involved permitted dissolution by majority vote "unless otherwise provided in the agreement of association," and although the agreement given effect was not the "agreement of association" specified, the Massachusetts statute is certainly more obviously permissive than $\S 4600$.

In Fish v. Nebraska City Barb-Wire Fence Co., 25 Fed. 795, 796 (C.C.D. Neb. 1885), it was held that "althougl the statutes of Nebraska provided ways and means for working the dissolution of a corporation, such an agreement, signed by all the stockholders, was valid inter sese. ... The owners of property can make any contract for its disposal not forbidden by law, or against public policy or good morals." See also, to the same effect, RKO Theatres v. Trenton-New Brunswick Theatres Co., 8 N.J. Super. 404, 414, 72 A.2d 914, 920 (Ch. 1950); Wolf v. Arant, 88 Ga. App. 568, 77 S.E.2d 116 (1953); St. Jolin of Vizzini v. Cavallo, 134 Misc. 152, 234 N.Y. Supp. 683 (Sup. Ct. 1929). 
tendency in the intermediate appellate courts to construe section 4600 as conferring a mandatory right. ${ }^{20}$ In the first place, the supreme court has recognized that the voluntary dissolution rights granted by statute are subject to equitable limitations. ${ }^{21}$ Secondly, it was stressed in In re Security Fin. Co. that dissolution under the facts of that case would prejudice neither nonconsenting shareholders nor third parties, and the dissolving shareholder had no other way out. ${ }^{22}$ These two considerations, when combined, suggest an interpretation of section 4600 that would strike a balance between mandatory and permissive. It is that section 4600 confers a voluntary dissolution right that may be altered or waived by the shareholders, subject to equitable limitations of fairness inter sese and lack of prejudice to third parties. Fairness to all the shareholders would demand that reasonable alternatives be provided for any statutory remedies waived. ${ }^{23}$

It is submitted that such an interpretation of the voluntary dissolution right in California is the most desirable one. Section 4600 should not be construed as conferring a mandatory right upon the shareholders which may not be altered by them in any manner. Neither should it be construed to permit a majority of the shareholders of a corporation to impose oppressive conditions upon the minority and then to lock them in by procuring a waiver of their dissolution rights. But there is no sound reason why the shareholders of a close corporation may not agree among themselves upon other methods of solving problems of deadlock and dissolution than those provided by statute, and if these methods are reasonable they should be given binding effect by the courts, although statutory rights are thereby deemed waived.

The difficulty with making voluntary dissolution rights mandatory is not only that such a construction nullifies any conflicting special dissolution provisions, but also that it jeopardizes the effectiveness of any procedures specially provided for the interual resolution of deadlocks. If voluntary dissolution is always available regardless of the reasonableness and practicality of other methods provided for the resolution of intracorporate disputes, many legitimate agreements of the shareholder-managers of a close corporation would be subject to unwarranted frustration.

THE PROVISTONAL DIRECTOR AND THE DEADLOCKED CORPORATION

Section 819 of the California Corporations Code ${ }^{24}$ provides a statutory remedy for certain types of deadlocks, apart from and in addition to voluntary and invol-

20 Both Stubbs $v$. Jones and In re Mayellen Apartments, Inc, were cited in In re Security Fin. Co., 49 Cal.2d 370, 380, 317 P.2d 1, 7 (1957), but only for the proposition that judicial supervision of dissolution was a matter of right if the statutory requirements of $\S 4607$ of the Corporations Code were met.

21 In imposing equitable limitations upon the voluntary right, the supreme court has read into $\S 4600$ something which the district court of appeal had previously held "just is not there, namely: personal motives of or presence or absence of bad faith on the part of shareholders representing 50 per cent of the voting power." In re Security Fin. Co., 308 P.2d 531, 534 (Cal. App. 1957) (vacated). It is evident that the supreme court has not construed dissolution rights under the California statutes in the same absolute terms as the lower courts.

2249 Cal.2d 370, 378, 317 P.2d 1, 6 (1957).

23 No case has been found where a voluntary dissolution statute has been held to override reasonable alternative procedures.

24 CAL. CORP. CODE $\S 819$ (a) provides: "If a corporation has an even number of directors who are equally divided and cannot agree as to the management of its affairs, so that its business cannot longer be conducted to advantage or so that there is danger that its property and business will be impaired and lost, the superior court of the county where the principal office 
untary dissolution proceedings. This section, which authorizes a court-appointed provisional director, offers to the California close corporation the intriguing possibility of a statutory solution for a deadlock that causes neither a permanent alteration of the corporation's structure nor a disruption of its business. However, because the statute contains both patent and latent limitations it is by no means a panacea for corporate paralysis.

Section 819 empowers a court, at the instance of one-half the directors or of the holders of one-third of the voting shares, ${ }^{25}$ to appoint a provisional director to serve until an existing deadlock has been broken. ${ }^{26}$ However, the statute is applicable only to corporations having "an even number of directors who are equally divided." It is, therefore, doubtful that the terms of the statute can, by any conceivable stretch of judicial interpretation, be extended to cover deadlocked corporations with an odd number of directors or with an unequal division on matters requiring a percentage vote greater than a simple majority for affirmative action. ${ }^{27}$

Problems of the applicability of section 819 also arise where a vacancy on the board exists which cannot be filled because of deadlock, and where directors refuse to attend meetings. If a vacancy is unfilled because the remaining directorshareholders are evenly split, the board should be considered as consisting of an even number of directors. Authorized but vacant positions should not be counted. ${ }^{28}$ Likewise, where the odd director refuses to function "an even number of directors who are equally divided" should be deemed to exist. ${ }^{28}$

In order to justify appointment of a provisional director section 819 requires that there exists a disagreement as to the management of corporate affairs which results in either an inability to carry on the business to advantage, or in a danger of loss of property to the corporation. These statutory requirements are sufficiently

of the corporation is located may, notwithstanding any provisions of the articles or by-laws of the corporation and whether or not an action is pending for an involuntary winding up or dissolution of the corporation, appoint a provisional director pursuant to this section. ..."

${ }^{25}$ No trial procedure is prescribed. However, it has been conceded that the appointment of a provisional director under $\$ 819$ requires "a trial in the usual manner provided by our law," and it has been beld that the order appointing a provisional director in such cases is appealable. Desert Club v. Superior Court, 99 Cal. App. 2d 346, 347, 221 P.2d 766 (1950). Proceedings under $\$ 819$ (a) are to be distinguished from those under $\S 4655$, which authorizes the appointment of a provisional director in an action for involuntary dissolution where the board is deadlocked. It has been held that in cases of deadlock during involuntary dissolution, an order appointing a provisional director under $\S 4655$ is ancillary to the dissolution proceedings, and therefore nonappealable. Edlund v. Los Altos Builders, 106 Cal. App. 2d 350, 355, 235 P.2d 28,30 (1951). Minority shareholders in involuntary dissolution proceedings can protect their rights by intervention. CAL. CoRP. CODE $\$ 4653^{\circ}$. Appointment pursuant to $\$ 4655$, being inter- locutory, may be reviewed on appeal from the final order of dissolution. Edlund v. Los Altos Builders, supra at 356, 235 P.2d at 31 .

26 A provisional director may be removed by either an order of the court or a majority vote of the voting shares. CAL. CoRp. CODE $\$ 819(\mathrm{~b})$.

${ }^{27}$ It is obvious that a board with an odd number of directors can be as effectively deadlocked as an even numbered board. Suppose a case where the articles provide that no action shall be taken by the directors unless more than two-thirds agree. If there are five directors and they are sphit two to three the same situation would be present as where there are four directors split two to two without a proportionate vote requirement. However, $\$ 819$ would not be available to the corporation having five directors.

28 It has been so held by implication. Desert Club v. Superior Court, 99 Cal. App. 2d 346, 221 P.2d 766 (1950).

29 There is no authority in California for this point, but it has been so held in construing identical statutory language in New York. Matter of the Petition of Binder, 258 App. Div, 1041, 17 N.Y.S.2d 1020 (1st Dep't 1940). 
vague to permit a court to exercise broad discretion in determining whether appointunent of a provisional director is justified.

A liberal approach was adopted in In re Jamison Steel Corp..${ }^{30}$ which generally construes section 819 as being broadly remedial. There a solvent, going concern was still able to continue operations profitably, but was unable to change either its policies or its directors because of a series of tie votes. On the issue of the existence of a disagreement as to management it was held that "perpetuation of existing policies or incumbent officers in office [was not] ... effectively managing corporate affairs." ${ }^{30 z}$ Moreover, it was found that the threat of an accumulated earnings tax due to inability to declare a dividend, disputes as to salaries of corporate employees, and excessive rent which the corporation was alleged to be paying to one of its shareholders for leased realty, were factors which, in combination at least, were sufficient to warrant a conclusion that the corporation was in danger of losing both property and business. ${ }^{31}$

It was argued in In re Jamison Steel Corp. that the appointment of a provisional director is analogous to the appointment of a receiver. However, it was held that the remedy afforded by section 819 , being less severe than receivership, was available in situations where a receiver was not justified. ${ }^{32}$ Differences between the powers of a provisional director and a receiver were emphasized in arriving at this conclusion. The court reasoned that while a provisional director is merely a temporary addition to the board possessing only the ordinary powers of any director ${ }^{33}$

30158 Cal. App. 2d 27, 322 P.2d 246 (1958).

$30 \mathrm{a}$ Id. at 37,322 P.2d at 251 .

31 In the instant case the court was confronted with what it termed "a model for the facts which will justify" appointment of a provisional director. Id. at 36,322 P.2d at 251 . A former partnership had incorporated, the original articles specifying a board of three directors. By subsequent amendment this numher was increased to four. Dissension commenced with a change in personnel on the board. It is difficult to ascertain which of the factors listed by the court is the most important in justifying a provisional director, and it should not be concluded that the sources of dissension found in this case are all-inclusive. Ineffective management of corporate affairs is the general test laid down, and any fact leading to this result would be relevant to the issue.

32158 Cal. App. 2d 27, 36, 322 P.2d 246, 251 (1958). The court stated that "there is a readily discernible difference between a corporation not able to conduct its business to advantage or being in danger of impairing and losing its property and a corporation which is in danger of cessation or diminution of operations." Ibid. However, the analogy between a provisional director and a receiver would seem to he more plausible than the court indicates, for any difference in the facts justifying either is one merely of degree. The wording of $\$ 819$ parallels much of the language used to justify receivership in cases decided prior to its enactment. In Boyle v. Superior Court, 176 Cal. 671, 674, 170 Pac. 1140, 1141 (1917), it is stated that "fraud is not a necessary basis for the procurement ... [ [of a receiver]. Dissensions, honest differences of opinion, phich result in making it impossible for the corporation to carry on its business to advantage ... . [are sufficient]." Moreover, a receiver may be appointed for a solvent, going concern with no prospect of dissolution. Califorma Fruit Growers' Ass'n v. Superior Court, 8 Cal. App. 711, 97 Pac. 769 (1908).

33 CAL. CORP. CODE $\$ 819(\mathrm{~b})$ in pertinent part provides: "The provisional director shall have all the rights and powers of a director, and shall be entitled to notice of the meetimgs of the board of directors and to vote at such meetings, until the deadlock in the board of directors is hroken or until he is removed by order of the court or by vote or written consent of the holders of a majority of the voting shares." The problem in interpreting this provision is phether the "rights and powers" specified are the full statutory rights, or those rights as they have been validly altered or restricted in the articles. One construction would be that since a provisional director is a statutory appointee he mnst possess all the rights and powers to which a director is entitled by statute, regardless of restrictions imposed by the articles. On the other hand, since the statutes themselves permit the authority of directors as to certain matters to be 
a receiver takes possession of all corporate property and assumes complete control of the conduct of the business. Moreover, in the minds of outsiders, receivership is associated with insolvency, thus producing a detrimental effect upon a corporation's general credit. On the other hand, appointment of a provisional director should have no such impact upon outside creditors. ${ }^{34}$

From In re Jamison Steel Corp. it is safe to conclude that a court will be quick to find the requisite disagreement among directors resulting in danger of loss to the corporation, once it has been established that, due to dissension, the corporation is not being effectively managed. Effective management means something more than a preservation of the status quo; it apparently includes an ability to change existing policies. ${ }^{35}$ The fact that the corporation is still operating at a profit will not preclude the appointment of a provisional director. And finally, the origins of a particular deadlock or the good faith of the parties to it are irrelevant, the controlhing issue being whether a deadlock exists and not why it exists. ${ }^{36}$

Section 819 , limited as it is to corporations with even-numbered, equally divided boards of directors, is a remedy that is particularly vulnerable to avoidance by adequate planning. An odd number of directors may be specified in the articles, and if an equal allocation of power between two factions is desired, an appropriate percentage vote may be required for board action. ${ }^{37}$ Perhaps a simpler alternative would be to specify an even number of directors but to provide for a percentage vote other than a simple majority for major management decisions. Thus deadlocks would occur when the board is not equally divided. In either case, the result should be to preclude the appointment of a provisional director when a deadlock occurs.

circumscribed in the articles, it may be argued that a provisional director has only the rights and powers of any other director in the particular corporation to which he is appointed. It is submitted that the latter construction is more in line with the purpose of 8819 as an ordinary, rather than a drastic remedy.

34 The power of a court of equity to appoint a receiver for a corporation in circumstances not involving insolvency or dissolution is provided by CAL. CODE Crv. PrOC. $\$ 564$. Section 819 does not supersede this inherent equity power. Golden State Glass Corp. v. Superior Court, 13 Cal.2d 384, 90 P.2d 75 (1939) (case decided after passage of $\$ 819$ in its present form). Therefore, receivership is another remedy available in cases of deadlock where corporate paralysis is complete. It should not be overlooked as a possibility where $\$ 819$ is not applicable because of an odd-numbered board.

35 Lack of effective management as a test for the appropriateness of a provisional dircctor is open to the objection that it is one which permits a court to exercise business judgment ratber than judicial discretion.

36 In re Jamison Steel Corp., 158 Cal. App. 2d 27, 39, 322 P.2d 246 (1958). In that case it was contended that tie votes were a device used by one faction for the procurement of a provisional director who could then be influenced by that faction to vote to amend the articles to increase the board to an odd number which would ultimately enable that faction to gain control of the corporation. The refusal of the court to investigate the motives of either faction could lead to abuse of the provisional-director remedy in that it would not be difficult for one faction to stir up enough dissension in a close corporation to preclude effective management. Thereafter, since the provisional director's primary statutory responsilility is to break the deadlock, the best-way for him to do this in many cases would be to tip the scales in favor of one faction. If the faction promoting the dissension is also the faction seeking a provisional director, it is likely that the appointee would listen first to those responsible for his appointment regardless of how impartial he is. It is submitted that either a requirement of good faith should be imposed upon those seeking appointment of a provisional director, or else a duty should be imposed upon the person appointed not to jeopardize the rights of one faction in the interest of breaking a deadlock.

37 See note 27 supra and accompanying text. 
Since the purpose of section 819 is to provide a remedy for close corporations with deadlocked boards of directors, it is submitted that there should be no distinction based on the type of board or on the manner in which a deadlock comes about so long as the required deadlock exists. Accordingly, section 819(a) should be amended to read as follows: "If a corporation has a board of directors which cannot agree as to the management of its affairs ...."

Assuming, however, a situation in which the corporation has an even number of directors who become equally divided, there is little, if anything, that the planner can do to prevent resort to section 819 . The statute expressly supersedes contrary provisions in the articles or by-laws. ${ }^{38}$ The status of a shareholders' agreement is more doubtful. However, in the context of a close corporation, an agreement between all the shareholders is inter sese not different in its binding effect from a provision in the articles or by-laws. Therefore, a court should not permit a shareholders' agreement in this type of case to short circuit the effect of section 819 and to accomplish what expressly cannot be done by articles and by-laws. ${ }^{39}$

One final observation in regard to the possibilities of breaking a deadlock by resort to section 819 must be made. As a remedy for deadlock with a minimum of disruption to the corporation involved, the advantages of the provisional director statute are obvious. But the provisional director is at best a tie-breaker. It would seem that if he exercises his powers with the requisite impartiality the rehef to be obtained by his appointment is akin to compulsory arbitration. Therefore, a provisional director may provide valuable assistance over rough spots when they are relatively few and far between and the points of disagreement are sharply defined. But a permanent solution to deadlocks caused by general disagreement on management policies should not be expected.

Mason Willrich 